\title{
1. What we wish we had known: lessons learned to keep your doctorate on track
}

\section{Rebecca Loudoun, Emily A. Morrison, Mark N.K. Saunders and Keith Townsend}

Over the years we have often talked with one another, with our doctoral students, and with numerous colleagues and friends about how doctoral students and supervisors/advisors might be better supported on their doctoral journeys. Recognizing the richness of both students' and supervisors' lived experiences, and the importance of their insights and learning to others in helping to keep doctorates on track, we have chatted long into the night about how we might make their and others' stories, what they now know, and the lessons they have learned more accessible.

This book brings together contributions from authors across the world and from a variety of disciplinary backgrounds. It is about the realities doctoral researchers in the social sciences face on a day-to-day basis. Unlike the majority of books about doctoral research and research methods texts, it places centre stage, their lived experiences from the perspective of current and past candidates, as well as supervisors. Our aim in compiling this book is to offer insights to those thinking about (or presently undertaking) doctoral research and those supporting them. While everyone's experiences (and doctorates) are unique, it is important to recognize that there are some commonalities too. The book is meant to be a companion for your doctoral journey, from the first thoughts of 'how to begin' through to submission and finding that first job. We aim for the book to be as close as possible to sitting and chatting with a friend or trusted advisor over a cup of coffee, tea, or even a gin and tonic. This is not a step-by-step procedural text; rather, it is about the realities that others have experienced during the doctoral process, and through these it gives a platform for their insights, advice and lessons regarding the realities of the doctoral process. 
The doctoral process usually starts with wanting to pursue a doctorate, often for a variety of reasons and with a variety of intended outcomes along with, invariably, a desire for a successful completion. Perhaps you want to start a second career, or advance within your organization or answer a question that you've been thinking about for years. Maybe you're already enrolled in a programme and are completing or have completed your coursework, and want help either planning ahead or navigating snags/obstacles you never even realized you would encounter. Some of you could be supervising students completing a doctorate programme and looking to give them insight into the possible waters ahead (and hopefully help them chart a smooth sail!). To achieve successful completion, and sail to your final port, you generally have to undertake a substantial piece of research and write an associated document (called a dissertation in some countries and a thesis in others).

Whichever of these scenarios describes you, we believe this book can help. It is edited by the four of us, who, together, have experience of the wide variety of different forms of doctorates and how they are delivered and examined across different continents. While we cannot offer a full and complete chart of the doctoral seas, we believe this book will help you get a better sense of the waters you will sail through on your doctoral journey. Like the charts of times gone by, there may be places where you will sail that are as yet unmapped. You will experience some of the most exciting and exhilarating moments of your life through the doctoral process, yet you will face complex situations that seem impossible to navigate. However, we believe that, through reading and reflecting on others' experiences, you will be better able to navigate the doctoral process, identifying potential courses and hazards so you can sail round them with minimal disruption. We also hope that, if, despite working diligently, you still find yourself blown off course, this book will offer reassurance, support and direction.

Generally speaking, within the social sciences, the doctoral process involves undertaking research and crafting a thesis or dissertation of about 80,000 words. Some will be based on empirical research, others will be more hypothetical; some will be concerned with developing theory, others will be more applied to the world of practice; but all will be based on argument and evidence and involve an original contribution of some form.

Our general view is that it's important to become a researcher who understands and is able not only to create knowledge in an ethical way, but also to share that knowledge for the greater good. People are not born with the title 'Doctor' or 'Professor'; rather, it takes concerted effort to learn (and unlearn!) how to be a knowledgeable, ethical 
researcher. There will be times in this developmental process when you (whether you are the student or the supervisor/advisor) are learning from and following the other, as well as times where you are teaching and leading the other. Completing doctoral research is a dynamic process where we learn from and with one another. The ultimate aim is to discover and contribute new insights about the world and our role in it. This requires honing one's abilities to be curious, challenge assumptions, think critically, apply findings in ethical ways, and be savvy creators and consumers of information.

As such, it's important to remember the old proverb, 'Forewarned is forearmed'. In other words, the more informed you are about the process and possible (likely?) stormy weather ahead, the better able you will be to navigate the challenges with minimal disruptions. We believe this is important for both students and supervisors; it is our experience that most supervisors (including ourselves at times) tend to rely on their own experiences of their doctoral programme when thinking about the doctoral journey. As we said earlier, while there are certain commonalities, there is considerable variation too. Therefore, this book is intended for both students and supervisors to provide broad exposure to experiences and insights from around the globe. Research consistently shows that students are also more likely to finish their research degrees if they have a positive student-supervisor working relationship based around agreed expectations and common understanding of the process (Johansson and Yerrabati, 2017; McCulloch et al., 2016; Morrison et al., 2011).

Over time, doctoral candidates' roles will change. Initially, doctoral candidates will be learning as much as they can. As they progress through the process, they develop expertise in the field and become scholars. Indeed, emerging scholars may in fact become the teachers, teaching their supervisor, community at large, etc. about the impact of their work. For those who stay in academia, they will need to build a research career, to supervise other students and to become the 'judge' or examiner of other people's doctoral theses or dissertations. By sharing insights from current students, recent alumni, supervisors (our own experiences included) and examiners about the frustrations and uncertainties of the doctoral process, we hope to inform and help students reflect on their own experiences. In so doing, we hope they will be better prepared and supported to navigate their own journeys successfully.

This book can be read by just focusing on a few chapters at a time or by reading from cover to cover in one sitting. Feel free to just skim a chapter or two, jump around, come back to certain chapters and vignettes. Despite what you may have been led to believe, and the structure of this book, completing doctoral research is often not a linear process. 
The book brings together 59 contributions from across the globe by people that are enrolled in their doctorate, have completed their doctorate or have supervised other people's doctorates. The chapters tell of what they learned (sometimes through trial and error) or didn't learn going through and supporting others to navigate their journeys. However, while we have tried to include a variety of perspectives and more universal/ common experiences across contexts, it's important to say from the outset that we are cognizant not all of the chapters may resonate with your own experiences and, also, that one resource can't fully inform or prepare anyone for the full range of realities of doctoral research. Along with periods when everything is going well, there will be so many difficult decisions, challenges, hiccups and indeed failures (many of which may be unpredictable or unanticipated) between the starting point and, following successful completion, the first post-doctorate job. We consider the process of doing a doctorate as much broader than simply the conducting of the research, and hence we consider topics beyond this official candidature phase such as selecting a supervisor and indeed a university, publishing, dealing with feedback, undertaking revisions required by examiners and finding the first job.

We believe this book is pertinent not only to the most common form of doctorate, that is the Doctor of Philosophy, but also to the variety of new doctoral degree programmes that have emerged to meet the challenges of the modern academic environment, including calls for stronger links between academic research and 'end users' such as industry, society and government entities. These programmes (summarized later in Table 1.1) are not intended to differ in their rigour or the skills they produce in the candidate (they are all located at doctoral level in terms of academic standard and, importantly, all graduates are entitled to call themselves Doctor!), but rather in terms of the student that might be attracted to them and the forum to which they aim to contribute their required new knowledge. Nonetheless the different programmes often have different outputs, result in awards with different titles and are structured differently.

According to the Organisation for Economic Co-operation and Development (OECD, 2016), the past two decades have witnessed a steady increase in the number of doctoral degrees being awarded worldwide. However, higher education is facing a number of significant challenges fuelled by factors such as globalization, technology and funding; and evolving faculty models and doctoral programmes are, invariably, also affected. In response to these challenges, new models of doctorates are being proposed along with changes to entry requirements and associated training. 
Table 1.1 Summary of common modern doctoral awards

\begin{tabular}{|c|c|c|c|c|}
\hline Type & $\begin{array}{l}\text { Example } \\
\text { awards }\end{array}$ & Focus & Training & $\begin{array}{l}\text { Doctoral } \\
\text { assessment }\end{array}$ \\
\hline Traditional & $\begin{array}{l}\text { PhD, } \\
\text { DPhil }\end{array}$ & $\begin{array}{l}\text { Subject-focused } \\
\text { research } \\
\text { project }\end{array}$ & $\begin{array}{l}\text { Generic } \\
\text { research skills }\end{array}$ & $\begin{array}{l}\text { Thesis/ } \\
\text { dissertation (+ } \\
\text { oral defence*) }\end{array}$ \\
\hline $\begin{array}{l}\text { Integrated/ } \\
\text { new route }\end{array}$ & $\begin{array}{l}\text { PhD, } \\
\text { DPhil }\end{array}$ & $\begin{array}{l}\text { Taught } \\
\text { components }+ \\
\text { subject-focused } \\
\text { research } \\
\text { project }\end{array}$ & $\begin{array}{l}\text { Assessed } \\
\text { programme } \\
\text { research skills } \\
+ \text { other } \\
\text { modules }\end{array}$ & $\begin{array}{l}\text { Thesis/ } \\
\text { dissertation (+ } \\
\text { oral defence*) }\end{array}$ \\
\hline Professional & $\begin{array}{l}\text { DBA, } \\
\text { EdD }\end{array}$ & $\begin{array}{l}\text { Taught } \\
\text { components }+ \\
\text { professional- } \\
\text { focused } \\
\text { research } \\
\text { project }\end{array}$ & $\begin{array}{l}\text { Assessed } \\
\text { programme } \\
\text { research skills } \\
+ \text { other } \\
\text { modules }\end{array}$ & $\begin{array}{l}\text { Thesis/ } \\
\text { dissertation (+ } \\
\text { oral defence*) }\end{array}$ \\
\hline $\begin{array}{l}\text { Practice } \\
\text { based }\end{array}$ & $\mathrm{PhD}$ & $\begin{array}{l}\text { Taught } \\
\text { components }+ \\
\text { practice-focused } \\
\text { research } \\
\text { project }\end{array}$ & $\begin{array}{l}\text { Assessed } \\
\text { programme } \\
\text { research skills } \\
+ \text { other } \\
\text { modules }\end{array}$ & $\begin{array}{l}\text { Portfolio/artefact/ } \\
\text { composition with } \\
\text { overarching } \\
\text { critical } \\
\text { commentary (+ } \\
\text { oral defence*) }\end{array}$ \\
\hline $\begin{array}{l}\text { By } \\
\text { publication }\end{array}$ & $\mathrm{PhD}$ & $\begin{array}{l}\text { Peer-reviewed } \\
\text { publications }\end{array}$ & - & $\begin{array}{l}\text { Portfolio of } \\
\text { interrelated } \\
\text { publications with } \\
\text { integrative } \\
\text { commentary (+ } \\
\text { oral defence*) }\end{array}$ \\
\hline
\end{tabular}

Note: * Not all institutions require an oral defence.

Sources: $\quad$ Developed from Banerjee and Morley (2013); Burmeister (2015); Park (2005, 2007)

Not surprisingly, there is considerable debate about the merits of the various models and whether it is the end product, the process or both product and process that are important for awarding the degree. Common to all models, remains a clear view that the learning's gathered through a doctorate and the independent scholar/researcher who emerges at the other end is as important as the dissertation or thesis. To edge worryingly close to clichés - the journey you actually sail can be the most important part of the research!

The expansion of the professional doctorate is one example aiming to have more direct relevance to practitioners and/or industry (Banerjee and 
Morley, 2013). The sector holds mixed views about them, but at their best professional doctorates are "based on development projects which result in substantial organizational or professional change and ... a significant contribution to practice' (Lester, 2004, p. 757).

Another increasingly common option is the $\mathrm{PhD}$ by Publication, where candidates are awarded a doctorate based on their publishing activity. This allows a researcher to become $\mathrm{PhD}$ qualified through publishing journal articles and bringing their contribution together as a collective, rather than completing a single $\mathrm{PhD}$-length thesis from which the candidate then seeks to publish. Other examples are the Doctorate in Education (EdD) and the Doctor of Business Administration (DBA) degree and practice-based research degrees in art and design. Regardless of the doctoral programme name, however, the applicant is typically required to have already completed an undergraduate degree and a bridging degree (Honours or Master's) to demonstrate an adequate understanding of the research process.

We should also acknowledge there are differences in $\mathrm{PhD}$ programmes throughout the world and between universities. For example, in the USA, a doctorate programme usually includes both taking advanced-level courses (taught components) and undertaking academic research, with access to a range of academic advisors and supervisors along the way. In Europe (including the UK) and Australia, the doctorate is typically based largely on research with varying amounts of formal (perhaps nonassessed) training; the student effectively serves an apprenticeship under the guidance of a supervisory team of up to three people.

In most countries, the primary emphasis within the doctorate is on developing disciplinary knowledge, in preference to applied research and knowledge transfer. A strong emphasis on preparing students for any roles (within or beyond the academy) they might expect to fill after completing their doctorate remains rare. Terminology can vary - some people refer to supervisors, some people use the term mentors and others 'advisors'. There are also differences in how the research is examined by 'correspondence', as is the case in Australia where the written thesis is examined and the examiner and student may never meet, or the oral defence (Viva) experience in which the examiner reads the thesis and then faces the student, who has to defend their work to the panel of examiners. In some parts of the world, for example Scandinavian countries, the examination experience is much more of a public celebration of the new graduate.

Despite these and many more differences, there are commonalities. Supervisors experience joy and become frustrated, students get excited and terrified, and families and friends - unless they've earned a doctorate 
themselves - may not understand what the person is doing (or why!). We know we will miss some things in this book, but a blank page tells us nothing at all.

So, what do we wish we'd known about the doctoral research process? First, it's important to acknowledge how daunting (and possibly even overwhelming) this venture might seem. Even thinking about the entire doctoral research process at once can be overwhelming. Hence, we structure the book by looking at the journey in three distinct phases, from the inception of and ideas for doctoral research (Part I: Getting into it); to the research phase itself (Part II: Getting on with it); to completing the dissertation or thesis, being examined and moving on (Part III: Getting it finished and moving on). Each of these three sections starts with a table that records the associated chapters' and vignettes' authors and titles, the viewpoint from which each is written, and a brief summary of the main focus.

We believe the reflections, insights and lessons learned within each of the chapters and vignettes are important for both students and those mentoring/supervising students. For students we trust these will offer the insights and companionship needed not only to keep your doctorate on track, but also to help you to reflect during your own doctoral journey and learn, grow and hopefully thrive throughout the process. As supervisors, we recognize that taking the journey through the doctoral process with students can become such an ingrained part of our role that we take for granted or forget to appreciate that some students need more or less direction with various parts of the journey than others. We therefore hope the chapters and vignettes stimulate supervisors, as they did us, to pause and reflect upon our own practice.

Insights and lessons learned are explored throughout each section of the book with 'paired chapters' - a supervisor or academic advisor perspective and a student perspective with additional vignettes together give food for thought and insights into practical ways to navigate the process. They are not paired at a research team level, that is, the supervisor and the student contributions do not hold relationships with each other; rather, we have selected authors who can provide insight into the particular topic. Our intention is not to compare potential differences in student and supervisor perceptions. Instead, by sharing lived experiences from different points of view along the doctoral research process, we have tried to offer a more nuanced and rounded perspective on the realities of undertaking and completing a doctorate. You will therefore see similarities and differences in viewpoints within each pair of perspectives. 
Another reason we chose to present paired chapters of each topic is because, while a supervisor or academic adviser generally guides doctoral candidates through the project to completion and graduation, research suggests that their perceptions of the doctoral process rarely align with candidates' perceptions of their experience or needs (Taylor et al., 2018). A good way to illustrate this is to think about it in terms of a parent-teenager relationship or a professional trainer with an athlete trying to excel in their sport. If the teenager was left to make all of their own decisions, they would turn to TV, YouTube, Facebook, Instagram, Snapchat, video games all day long punctuated by the occasional trip to the kitchen to get another cola and chocolate bar or bag of chips (crisps). Parents have to provide guidance, just as supervisors need to guide the students - but it is the student's project!

Looking at the professional trainer, they need to guide and support the athlete through the many and varied options for increasing fitness and finessing skills. Just as athletes bring different life experiences, personalities, expertise, abilities, identities to the arena, so too will doctoral candidates (and indeed so too will supervisors). Ultimately, though, it is the student's work just as it's the athlete's preparation, training and outputs (and ultimately performance on the day!) that count. As in the case of trainers of professional athletes, it can take considerable time and effort for supervisors to listen and meet students where they are and to help them get to where they need to be.

Wherever you are in your experience, and whatever is your motivation for using this book, we wish you well. We hope that this becomes another supportive resource for you as you move from being a sailor to the captain of your own ship in the journey to complete a doctorate and continue to develop subsequently.

\section{REFERENCES}

Banerjee, S., and Morley, C. (2013). 'Professional doctorates in management: toward a practice-based approach to doctoral education'. Academy of Management Learning \& Education, 12(2), 173-93.

Burmeister, O.K. (2015). 'Improving professional IT doctorate completion rates'. Australasian Journal of Information Systems, 19, 55-70.

Johansson, C., and Yerrabati, S. (2017). 'A review of the literature on professional doctorate supervisory styles'. Management in Education, 31(4), 166-71.

Lester, S. (2004). 'Conceptualizing the practitioner doctorate'. Studies in Higher Education, 29(6), 757-70.

McCulloch, A., Kumar, V., van Schalkwyk, S., and Wisker, G. (2016). 'Excellence in doctoral supervision: an examination of authoritative sources across 
four countries in search of performance higher than competence'. Quality in Higher Education, 22(1), 64-77.

Morrison, E., Rudd, E., Zumeta, W., and Nerad, M. (2011). 'What matters for excellence in $\mathrm{PhD}$ programs? Latent constructs of doctoral program quality used by early career social scientists'. The Journal of Higher Education, $82(5), 535-63$.

OECD (2016). OECD Science, Technology and Innovation Outlook 2016. Paris: OECD Publishing.

Park, C. (2005). 'New variant PhD: the changing nature of the doctorate in the UK'. Journal of Higher Education Policy and Management, 27(2), 189-207.

Park, C. (2007). Redefining the Doctorate. York: The Higher Education Academy.

Taylor, R.T., Vitale, T., Tapoler, C., and Whaley, K. (2018). 'Desirable qualities of modern doctorate advisors in the USA: a view through the lenses of candidates, graduates, and academic advisors'. Studies in Higher Education, 43(5), 854-66. 